\title{
In vitro evaluation of the leishmanicidal potential of selected plant-derived extracts against Leishmania (Leishmania) amazonensis
}

\begin{abstract}
Background: Leishmaniasis is a potentially fatal, neglected parasitic disease caused by different species of Leishmania sp. Natural products, especially from plants; represent a rich source for the screening of potential antiparasitic compounds.

Purpose and study design: In this study, we evaluated the leishmanicidal activity of thirteen plant extracts against the parasite Leishmania (Leishmania) amazonensis in vitro, the cytotoxic and hemolytic activity. The extracts with activity against the parasite, was determined the chemical constituents.

Results: The hexane extracts of Bidens sulphurea and Plectranthus neochilus were the most effective extracts against promastigote forms at $24 \mathrm{~h}$ and $48 \mathrm{~h}$. The $\mathrm{EC}_{50}(50 \%$ effective concentration) value obtained for these extracts against promastigote forms were calculated to be $84.26 \mu \mathrm{g} / \mathrm{mL}$ and $46.32 \mu \mathrm{g} / \mathrm{mL}$ in $24 \mathrm{~h}$, respectively. The $\mathrm{EC}_{50}$ values against intracellular amastigotes were higher than $100 \mu \mathrm{g} / \mathrm{mL}$ after $48 \mathrm{~h}$ of incubation for both extracts. Regarding cytotoxicity in peritoneal macrophages, extracts of $B$. sulphurea showed $\mathrm{CC}_{50}$ values (cytotoxicity concentration of $50 \%$ of cells) of 103.9 and $80.30 \mu \mathrm{g} /$ $\mathrm{mL}$ at 24 and $48 \mathrm{~h}$, respectively, whereas the $\mathrm{CC}_{50}$ values for the P. neochilus extract were 66.95 and $34.39 \mu \mathrm{g} / \mathrm{mL}$ at 24 and $48 \mathrm{~h}$, respectively. The extracts showed no significant hemolysis at the concentrations evaluated, and the $\mathrm{CH}_{50}$ values were higher than $100 \mu \mathrm{g}$ / $\mathrm{mL}$. The chemical constituent of the hexane extracts of $B$. sulphurea and $P$. neochilus and their activity against $L$. amazonensis has not been previously described.
\end{abstract}

Conclusion: Despite the unsatisfactory results against amastigotes forms, this study shows extracts obtained from botanical sources merit further study for their leishmanicidal properties.

Keywords: Leishmania (Leishmania) amazonensis, natural products, hexane plant extracts, leishmanicidal activity

Abbreviations: VL, visceral leishmaniasis; CL, cutaneous leishmaniasis; GC, gas chromatography; MS, mass spectrometry; FBS, fetal bovine serum; DMSO, dimethyl sulfoxide; $\mathrm{EC}_{50}, 50 \%$ effective concentration; $\mathrm{CC}_{50}, 50 \%$ cytotoxic concentration; $\mathrm{HC}_{50}$, $50 \%$ hemolytic concentration; SD, standard deviation; SI, selectivity index

\section{Introduction}

Leishmaniasis, one of the most important neglected tropical diseases, is endemic in 98 countries, with more than 12 million cases and 350million people living in areas at risk of infection. ${ }^{1,2}$ This disease is caused by an obligate intracellular protozoan of the genus Leishmania, ${ }^{3}$ and is broadly classified into three different forms: visceral leishmaniasis (VL), cutaneous leishmaniasis (CL) and mucocutaneous leishmaniasis. ${ }^{4}$ In Latin America, Leishmania (Leishmania) amazonensis is responsible for the cutaneous diffuse form of the disease, ${ }^{5}$ that in some cases may also result in visceral leishmaniasis. ${ }^{6,7}$ According to the Brazilian Ministry of Health, since 2005, the presence of L.(L.) amazonensis has been present in almost all Brazilian regions ${ }^{5}$, thus raising concern about this infection. The first-line drugs for leishmaniasis treatment are sodium stibogluconate (Pentostan) and meglumine antimonite (Glucantime); amphotericin $\mathrm{B}$ and pentamidine are second-line drugs. ${ }^{2}$ However, the current standard-of-care is unsatisfactory due to are expensive, potentially toxic and long-term treatment requirements, resulting in patient non-
Volume 12 Issue I - 2019

\author{
Julia M Souza,' Ana Carolina BB Candido,' \\ Mariana C Pagotti,' Herbert J Dias, ${ }^{2}$ \\ Gabriela P Aguiar,' Andréia T Arantes, ${ }^{3}$ \\ Wilson R Cunha,' Milton Groppo, ${ }^{4}$ Antônio \\ EM Crotti, ${ }^{2}$ Renato LT Parreira,' Jean A \\ Bernatchez, ${ }^{5}$ Lizandra G Magalhães' \\ 'Núcleo de Pesquisas em Ciências Exatas e Tecnológicas, \\ Universidade de Franca,Av. Dr. Armando Salles Oliveira, Brazil \\ ${ }^{2}$ Departamento de Química, Faculdade de Filosofia, Ciências e \\ Letras de Ribeirão Preto, Universidade de São Paulo, Brazil \\ ${ }^{3}$ CENTAGRO - Centro Tecnológico Agropecuário, Rua Prudente \\ de Morais, Brazil \\ ${ }^{4}$ Departamento de Biologia, Faculdade de Filosofia, Ciências e \\ Letras de Ribeirão Preto, Universidade de São Paulo, Brazil \\ ${ }^{5}$ Skaggs School of Pharmacy and Pharmaceutical Sciences, \\ University of California San Diego, United States
}

Correspondence: Lizandra Guidi Magalhães, I Núcleo de Pesquisas em Ciências Exatas e Tecnológicas, Universidade de Franca, Av. Dr.Armando Salles Oliveira, 20I, Pq. Universitário, CEP I4404-600, Franca, SP, Brazil, Tel +55 I6 37II 887I, Email lizandra.magalhaes@unifran.edu.br

Received: July 08, 2018 | Published: February 20, 2019 compliance. ${ }^{2}$ Also, there are significant differences in the sensitivity of these species to standard drugs. ${ }^{8,9}$

In the last decade, the scientific investigation of medicinal plants has received considerable attention in drug development against protozoan diseases. ${ }^{10-12}$ In this context, the evaluation of plant-derived extracts and isolated natural compounds can result in potential leads for use against infectious diseases. Recently, it was demonstrated that the hexane extracts derived from plants of Asteraceae, Lamiaceae, Myrtaceae, and Verbenaceae families showed promising activity against cariogenic bacteria. ${ }^{13}$ As part of our ongoing interest in the antiparasitic activity of natural products and their derivatives, we evaluate here the leishmanicidal potential of thirteen selected plantderived hexane extracts from the leaves of herbaceous or arbustive plant species (Table 1) against the parasite $L$. (L.) amazonensis.

\section{Material and methods}

\section{Plant material and extraction}

Specimens of thirteen species (Table 1) were collected in May 2010 at "Sítio 13 de Maio" (20²6’S 47²7’W 977m), localized near the city of Franca, State of São Paulo, Brazil and identified by Prof. Dr. Milton Groppo. Voucher specimens were deposited at the Herbarium of Departamento de Biologia, Faculdade de Filosofia, Ciências e Letras de Ribeirão Preto, Universidade de São Paulo, São Paulo, Brazil. Leaves of each species were dried carefully in a 
circulating air oven (Quimis-Diadema, BR) at $40^{\circ} \mathrm{C}$ and ground in a knife mill (Tecnal - Piracicaba, BR).

The powdered leaves were extracted with hexane, as previously reported. ${ }^{13}$ Three extractions per species were retained, with each extraction lasting $15 \mathrm{~min}$. The samples were concentrated using a rotary evaporator under reduced pressure to provide the respective hexane extracts.

\section{Gas Chromatography (GC) and gas chromatography mass spectrometry (GC-MS) analyses}

Gas chromatography-mass spectrometry (GC-MS) analyses was carried out as previously reported..$^{13}$ The chemical components of the hexane extract of Bidens sulphurea were identified on the basis of their retention indices relative to a homologous series of $n$-alkanes $\left(\mathrm{C}_{8}-\mathrm{C}_{40}\right)^{14}$ on a Rtx-5MS capillary column under the same operating conditions and computer matching with the Wiley 7, NIST 08 and FFNSC 1.2 spectral libraries of the GC-MS system.

\section{Animals}

Male BALB/c mice were maintained under controlled conditions of temperature $\left(22 \pm 20^{\circ} \mathrm{C}\right)$, humidity $(50 \pm 10 \%)$, and light-dark cycle. All the experiments were authorized by the University of Franca's Ethics Committee for Animal Care (Approval number: 046/15). All animals were handled using good animal practice as defined by the University of Franca in concordance with Brazilian legislation.

\section{Parasites}

L.(L.) amazonensis (MHOM/BR/PH8) was routinely in M199 medium (Gibco, New York, USA) supplemented with heatinactivated $10 \%$ fetal bovine serum (FBS), penicillin $(10000 \mathrm{UI} / \mathrm{mL})$ and streptomycin $(10 \mathrm{mg} / \mathrm{mL})\left(\right.$ Cultilab, Campinas, BR) at $25^{\circ} \mathrm{C}$.

\section{Anti-promastigote assay}

A preliminary screening with promastigote forms was performed in the presence of $100 \mu \mathrm{g} / \mathrm{mL}$ previously dissolved in dimethyl sulfoxide (DMSO) (Synth, Diadema, BR). The inhibition of cell growth was determined by counting cells with a haemocytometer (Global Glass, Porto Alegre, BR) after 24 and $48 \mathrm{~h}$ of incubation at $24^{\circ} \mathrm{C} .{ }^{15}$

The plant extracts that showed greater than or equal to $50 \%$ inhibition of cell growth during $48 \mathrm{~h}$ were further evaluated at concentrations of 0.78 to $100 \mu \mathrm{g} / \mathrm{mL}$. Parasites incubated with amphotericin B (Eurofarma-São Paulo, BR) was used as a positive control and M199 medium (Sigma Aldrich - St Louis, EUA) with $0.1 \%$ DMSO served as negative control. The $50 \%$ effective concentration $\left(\mathrm{EC}_{50}\right)$ was calculated as described below. All tests were conducted in triplicate, and three independent assays were performed.

\section{Anti-amastigote assay}

To evaluate activity against intracellular amastigote forms, peritoneal macrophages cells were seeded $\left(2 \times 10^{5}\right.$ cells $\left./ \mathrm{mL}\right)$ into $24-w e l l s$ plates containing glass coverslips $(13 \mathrm{~mm})$. Non-adherent cells were removed, and the cells were infected with promastigote forms at a ratio 1:10 (macrophage/promastigote). Infected macrophages were incubated with the $B$. sulphurea, $P$. neochilus $(6.25-100$ and $3.12-50 \mu \mathrm{g} / \mathrm{mL})$ and amphotericin B $(0.18-3 \mu \mathrm{g} / \mathrm{mL})$ for $48 \mathrm{~h}$ at the same conditions described above. Parasites incubated in RPMI 1640 medium (Sigma Aldrich) with 0.1\% DMSO served as the negative control. The number of amastigotes was determined by randomly counting 200 cells. The results were calculated using the negative control $(0.1 \%$ DMSO) as representative of $100 \%$ cell survival. The $50 \%$ inhibitory concentration $\left(\mathrm{EC}_{50}\right)$ was calculated as described below. All tests were conducted in triplicate, and three independent assays were performed.

\section{Cytotoxicity against peritoneal macrophages}

The obtation of peritoneal macrophages as performed using previously reported protocol with slight modification. ${ }^{16}$ The macrophages $\left(2 \times 10^{5}\right.$ cells $)$ were incubated in the presence of a concentration range $(0.78-100 \mu \mathrm{g} / \mathrm{mL})$ of Bidens sulphurea, Plectranthus neochilus and amphotericin B $(0.002-1.56 \mu \mathrm{g} / \mathrm{mL})$ (Eurofarma) for 24 and $48 \mathrm{~h}$. DMSO was used as a positive control $(25 \%)$ and negative control was RPMI 1640 medium with $0.1 \%$ of DMSO. Cell viability was assessed by Trypan Blue exclusion (Inlab -Diadema, BR).$^{17}$ The results were expressed as the mean percentage reduction of macrophage viability compared to that in the untreated control wells, and the $50 \%$ cytotoxic concentration $\left(\mathrm{CC}_{50}\right)$ was calculated as described below. All tests were conducted in triplicate, and three independent assays were performed.

\section{Red blood cell lysis assay}

The toxicity to red blood cells was determined as previously described with some modifications. ${ }^{18}$ Briefly, erythrocytes were incubated with $B$. sulphurea, $P$. neochilus and amphotericin B at room temperature for $30 \mathrm{~min}$ and hemolysis was determined by the hemoglobin release, quantitated by the absorbance of the supernatants at $415 \mathrm{~nm}$. The percentage of lysis was calculated in relation to total lysis. The negative control was erythrocytes with $\mathrm{NaCl}$ solution $0.9 \%$, while the positive control used erythrocytes with water. The $50 \%$ hemolytic concentration $\left(\mathrm{HC}_{50}\right)$ was calculated as described below. All tests were conducted in triplicate, and three independent assays were performed.

\section{Statistical analysis}

Data represent the mean number $( \pm \mathrm{SD})$ of three independent experiments performed in triplicate. The results were compared by analysis of variance, one-way ANOVA, followed by Dunnett's test to determine significance between the negative control group and treated groups. The $\mathrm{EC}_{50}, \mathrm{CC}_{50}$ and $\mathrm{HC}_{50}$ were calculated using doseresponse curves using GraphPad Prism 5 (GraphPad Software, San Diego, California, USA). The SI was calculated using the ratio of $\mathrm{CC}_{50} / \mathrm{EC}_{50}{ }^{19}$

\section{Results and discussion}

Several extracts and compounds isolated from plants have been investigated for their biological properties, including their leishmanicidal activit. ${ }^{20,21}$ In the present study, thirteen hexane extracts from leaves of cultivable herbaceous or arbustive plant species (Table 1) were evaluated against $L$. (L.) amazonensis. The hexane extracts of these species were selected on the basis of previous reports in the literature or on their use as antimicrobial and antiparasitic activities in folk medicine. ${ }^{13}$

A preliminary screening of hexane extracts was performed at $100 \mu \mathrm{g} / \mathrm{mL}$ against promastigote forms of $L$. (L.) amazonensis to select the most active extracts at higher concentrations. Five hexane extracts (Artemisia camphorata, Arrabidaea chica, Eclipta alba, Foeniculum vulgare, Lippia alba) showed no activity after $24 \mathrm{~h}$ and activity lower than $25 \%$ in $48 \mathrm{~h}$ of treatment. Six extracts (Alternanthera brasiliana, 
Coreopsis lanceolata, Pelargonium graveolens, Stachytarpheta cayennensis, Senna occidentalis and Tagetes erecta) showed a percentage of inhibition of cell growth of less than $50 \%$ at 24 and $48 \mathrm{~h}$ (Table 2). On the other hand, the hexane extracts of Bidens sulphurea and Plectranthus neochilus were the most effective extracts against promastigote forms of $L$. (L.) amazonensis at $24 \mathrm{~h}$ and $48 \mathrm{~h}$; they showed a percentage of inhibition of cell growth higher than $90 \%$ after 48h (Table 2).

Table I Classification and characteristics of the plant species selected for this study and their respective voucher number

\begin{tabular}{|c|c|c|c|c|}
\hline Family & Botanical name & $\begin{array}{l}\text { Voucher } \\
\text { number }\end{array}$ & Biological activities & References \\
\hline Amaranthaceae & $\begin{array}{c}\text { Alternanthera brasiliana (L.) } \\
\text { Kuntze }\end{array}$ & 10018 & Anti-inflammatory; analgesic & $\begin{array}{l}\text { Moraes et al., 1994; } \\
\text { Souza et al., } 1998\end{array}$ \\
\hline Apiaceae & Foeniculum vulgare Mill. & 12024 & $\begin{array}{c}\text { Diuretic; analgesic; antipyretic; } \\
\text { antioxidant }\end{array}$ & $\begin{array}{l}\text { Forster et al., 1980; } \\
\text { Tanira et al., 1996; } \\
\text { Oktay et al., 2003 }\end{array}$ \\
\hline \multirow{5}{*}{ Asteraceae } & Artemisia camphorata Vill. & 10006 & Antibacterial; Anti-fungal & $\begin{array}{c}\text { Itako et al., 2008; } \\
\text { Franzener et al., } 2003 .\end{array}$ \\
\hline & $\begin{array}{c}\text { Bidens sulphurea(Cav.) Sch. } \\
\text { Bip. }\end{array}$ & 12020 & NR & Botsaris 2007 \\
\hline & Coreopsis lanceolata L. & 10007 & $\begin{array}{c}\text { Antioxidant; eliminating free } \\
\text { radicals }\end{array}$ & $\begin{array}{c}\text { Crotti et al., 2013; } \\
\text { Tanimoto et al., } 2009\end{array}$ \\
\hline & Eclipta alba (L.) Hassk & 10008 & $\begin{array}{c}\text { Anti-fungal; antiepileptic; } \\
\text { antimicrobial }\end{array}$ & $\begin{array}{l}\text { Shaikh et al., 2013; } \\
\text { Karthikumar et al., } 2007\end{array}$ \\
\hline & Tagetes erecta $\mathrm{L}$. & 10009 & Antioxidant; Analgesic & $\begin{array}{l}\text { Lorenzi \& Souza, 2001; } \\
\text { Bashir \& Gilani, } 2008 .\end{array}$ \\
\hline Bignoniaceae & $\begin{array}{l}\text { Arrabidaea chica(Humb.\& } \\
\text { Bonpl.) B. Verl. }\end{array}$ & 10013 & $\begin{array}{l}\text { Collagen production; } \\
\text { antimicrobial; leishmanicidal }\end{array}$ & $\begin{array}{c}\text { Aro et al., 2013; } \\
\text { Mafioleti et al., 2013; } \\
\text { Rodrigues et al., } 2014\end{array}$ \\
\hline Fabaceae & Senna occidentalis (L.) Link & 10012 & Toxicity & $\begin{array}{c}\text { Barbosa-Ferreira et al., 2011; } \\
\text { Barros et al., } 1999\end{array}$ \\
\hline Geraniaceae & Pelargonium graveolens L' Hér. & 12023 & Antioxidant; anti-fungal. & $\begin{array}{l}\text { Cávar et al., 2012; } \\
\text { Singh et al., } 2008\end{array}$ \\
\hline Lamiaceae & Plectranthus neochilus Schltr. & 12323 & schistosomicidal; Antioxidant & $\begin{array}{l}\text { Caixeta et al., 2011; } \\
\text { Viana et al., } 2011\end{array}$ \\
\hline \multirow{2}{*}{ Verbenaceae } & Lippia alba (Mill.) N.E.Br & 12022 & $\begin{array}{c}\text { Antioxidant; } \\
\text { Antimicrobial }\end{array}$ & $\begin{array}{l}\text { Stashenko et al., 2004; } \\
\text { Aguiar et al., } 2008\end{array}$ \\
\hline & $\begin{array}{c}\text { Stachytarpheta } \\
\text { cayennensis(Rich.) Vahl. }\end{array}$ & 10005 & $\begin{array}{c}\text { Leishmanicidal; } \\
\text { Antimicrobial; Antispasmodic }\end{array}$ & $\begin{array}{l}\text { Moreira et al., 2007; } \\
\text { Okoye et al., } 2010\end{array}$ \\
\hline
\end{tabular}

NR: Not Reporte

Table 2 Screening in vitro of leishmanicidal activity against L.(L.) amazonensis promastigotes after 24 and $48 \mathrm{~h}$ of incubation with hexane plant extracts

\begin{tabular}{|c|c|c|}
\hline \multirow{2}{*}{ Species } & \multicolumn{2}{|c|}{$\%$ Inhibition of cell growth \pm SD } \\
\hline & $24 \mathrm{~h}$ & $48 \mathrm{~h}$ \\
\hline Alternanthera brasiliana & $4.12 \pm 1.71$ & $6.51 \pm 7.05$ \\
\hline Artemisia camphorata & $0 \pm 0$ & $19.13 \pm 3.93$ \\
\hline Arrabidaea chica & $0 \pm 0$ & $16.60 \pm 2.80$ \\
\hline Bidens sulphurea & $57.34 \pm 1.48$ & $92.72 \pm 8.05$ \\
\hline Coreopsis lanceolata & $0.11 \pm 0.16$ & $7.63 \pm 2.32$ \\
\hline Eclipta alba & $0 \pm 0$ & $0.69 \pm 0.97$ \\
\hline Foeniculum vulgare & $0 \pm 0$ & $5.66 \pm 4.38$ \\
\hline Lippia alba & $0 \pm 0$ & $21.20 \pm 0.96$ \\
\hline Pelargonium graveolens & $25.88 \pm 4.29$ & $41.58 \pm 2.67$ \\
\hline Plectranthus neochilus & $80.23 \pm 2.39$ & $92.19 \pm 2.62$ \\
\hline Stachytarpheta cayennensis & $39.38 \pm 1.29$ & $40.28 \pm 10.90$ \\
\hline Senna occidentalis & $12.64 \pm 2.04$ & $45.12 \pm 3.30$ \\
\hline Tagetes erecta & $2.10 \pm 2.97$ & $27.08 \pm .04$ \\
\hline Anfotericina $\mathrm{B}(2 \mu \mathrm{g} / \mathrm{mL})$ & $100 \pm 0$ & $100 \pm 0$ \\
\hline
\end{tabular}

Percentage of inhibition cell growth was calculated relative to the negative control (0.1\% DMSO).

Each experiment was performed in triplicate and repeated three times. 
Another study demonstrated that ethanolic extracts from Artemisia kulbadica, Artemisia cininformes and Artemisia santolina had an $\mathrm{EC}_{50}$ of 25.25 and $80 \mu \mathrm{g} / \mathrm{mL}$, respectively, against promastigotes forms of $L$. (L.) major after $24 \mathrm{~h}$ of incubation. ${ }^{22}$ However, no study has demonstrated the effect of $A$. camphorata extracts against $L$. (L.) amazonensis. As described previously in the literature, the hexane extract of $A$. chica showed $\mathrm{EC}_{50}$ values of $31.8 \mu \mathrm{g} / \mathrm{mL}$ and $14.7 \mu \mathrm{g} / \mathrm{mL}$ against $L .(L)$. amazonensis e $L$. (L.) infantum at $120 \mathrm{~h}$, respectively. ${ }^{23}$

In another study, the aqueous and ethanolic extract of $E$. alba inhibited $100 \%$ growth of $L$. (L.) donovani promastigotes at concentration of $0.5 \mathrm{mg} / \mathrm{mL}^{24}$ Besides, study demonstrated that essential oils obtained from the $L$. alba species collected at different locations in Colombia showed different leishmanicidal activities against L.(L.) chagasi promastigotes, which suggest that different location may show changes in the chemical composition of the plant. ${ }^{25}$ Maquiaveli and co-workers also reported that butanol fraction of the aqueous extract of $S$. cayennensis showed $\mathrm{EC}_{50}$ values of $51.0(72 \mathrm{~h})$ and $32.0(24 \mathrm{~h}) \mu \mathrm{g} / \mathrm{mL}$ against promastigote and amastigote forms, respectively. ${ }^{26}$

To determine the $\mathrm{EC}_{50}$ values of the hexane extracts of $P$. neochilus and $B$. sulphurea, promastigote forms of $L$. (L.) amazonensis were incubated with the hexane extracts for 24 and $48 \mathrm{~h}$. The activity of extracts has been classified as follows in the literature: highly active $\left(\mathrm{EC}_{50}\right.$ value $\left.<10 \mu \mathrm{g} / \mathrm{mL}\right)$; active, $\left(10<\mathrm{EC}_{50}<50 \mu \mathrm{g} / \mathrm{mL}\right)$, moderately active $\left(50<\mathrm{EC}_{50}<100 \mu \mathrm{g} / \mathrm{mL}\right)$ and non-active $\left(\mathrm{EC}_{50}>100 \mu \mathrm{g} / \mathrm{mL}\right) .{ }^{27}$ Our results revealed that in $24 \mathrm{~h}$ the hexane extract of $B$. sulphurea showed an $\mathrm{EC}_{50}$ value of $84.26 \mu \mathrm{g} / \mathrm{mL}(95 \%$ Confidence Interval $(95 \%$ CI) $81.23-87.56 \mu \mathrm{g} / \mathrm{mL})$ (moderately active), while hexane extract of $P$. neochilus showed a value of $46.32 \mu \mathrm{g} / \mathrm{mL}(95 \%$ CI$38.42-57.54 \mu \mathrm{g} / \mathrm{mL}$ ), considerate as moderate activity. In $48 \mathrm{~h}$, both extracts were considerate active, with $\mathrm{EC}_{50}$ values of 40.37 (95\% CI$29.64-55.64 \mu \mathrm{g} / \mathrm{mL})$ and $43.20 \mu \mathrm{g} / \mathrm{mL}(95 \%$ CI-39.57-50.87 $\mu \mathrm{g} / \mathrm{mL})$ for hexane extracts of B. sulphurea and P. neochilus, respectively. Amphotericin B showed an $\mathrm{EC}_{50}$ value of $0.011 \mu \mathrm{g} / \mathrm{mL}$ at $24(95 \% \mathrm{CI}-$ $0.0058-0.019 \mu \mathrm{g} / \mathrm{mL})$ and $0.012 \mu \mathrm{g} / \mathrm{mL} 48 \mathrm{~h}(95 \% \mathrm{CI}-0.0063-0.022 \mu \mathrm{g} /$ $\mathrm{mL}$ ) (Table 3 ).

According to Tempone and co-workers, the methanol extracts of Aristolochia cymbifera, Plectranthus amboinicus, Plectranthus barbatus and Lippia alba showed $\mathrm{EC}_{50}$ values of 45.14; 89.17; 54.46 and $62.67 \mu \mathrm{g} / \mathrm{mL}$, respectively against $L$. (L.) chagasi at $48 \mathrm{~h} .{ }^{28}$ In addition, the methanol extract of $P$. neochilus was inactive against Leishmania species. ${ }^{28}$ Another study, Antinarelli and co-workers demonstrated that the methanolic extract of $P$. neochilus showed active against $L$. (L.) chagasi, but it did not show activity against $L$.(L.) amazonensis, L.(L.) major and Leishmania (Viannia) braziliensi. ${ }^{20}$ Despite these results, it is interesting to notice that extracts methanolic and/or hexanic from the genus Plectranthus has showed values of $\mathrm{EC}_{50}$ considered active or moderately active, because of that this genus should be better investigated about its antiparasitic activity.

Although promastigotes can be used for fast screenings of potential compounds, the clinically relevant form of the parasite is the amastigote form, which shows metabolic differences from the extracellular forms. ${ }^{29,30}$ When the hexane extracts were evaluated against intracellular amastigotes, it was observed that after $48 \mathrm{~h}$ of incubation with $B$. sulphurea the $\mathrm{EC}_{50}$ value were $371 \mu \mathrm{g} / \mathrm{mL}(95 \%$ CI-254-487 $\mu \mathrm{g} / \mathrm{mL}$ ) and when incubated with $P$. neochilus the $\mathrm{EC}_{50}$ were $141 \mu \mathrm{g} / \mathrm{mL}$ (95\% CI-90.09-192.4 $\mu \mathrm{g} / \mathrm{mL}$ ), demonstrating that the hexane extracts have no activity against these parasitic forms. The
$\mathrm{EC}_{50}$ obtained after incubation with amphotericin B were $0.095 \mu \mathrm{g} /$ $\mathrm{mL}(95 \%$ CI-0.07-0.12 $\mu \mathrm{g} / \mathrm{mL}$ ) (Table 3).

An important criterion in the research of active compounds and extracts is to determine the absence of toxic effects on the host cells. In this study, the toxicity of hexane extracts of $B$. sulphurea and $P$. neochilus was evaluated on peritoneal macrophage. The hexane extract of $B$. sulphurea showed $\mathrm{CC}_{50}$ value $(50 \%$ cytotoxic concentration) of $103.9 \mu \mathrm{g} / \mathrm{mL}$ and $80.30 \mu \mathrm{g} / \mathrm{mL}(95 \%$ CI-99.46-128.98 $\mu \mathrm{g} / \mathrm{mL}$ and $73.15-88.15 \mu \mathrm{g} / \mathrm{mL}$, respectively) after 24 and $48 \mathrm{~h}$ of incubation. Moreover, the hexane extract of $P$. neochilus showed $\mathrm{CC}_{50}$ value of $66.95 \mu \mathrm{g} / \mathrm{mL}$ and $34.39 \mu \mathrm{g} / \mathrm{mL}(95 \% \mathrm{CI}-59.55-75.27 \mu \mathrm{g} / \mathrm{mL}$ and $28.21-$ 41.93 ) at 24 and $48 \mathrm{~h}$, respectively. Amphotericin B was more toxic to mammalian cell than hexane extracts, showing $\mathrm{CC}_{50}$ values of 4.29 and $2.98 \mu \mathrm{g} / \mathrm{mL}(95 \% \mathrm{CI}-3.25-6.77 \mu \mathrm{g} / \mathrm{mL}$ and $1.41-3.87)$ in 24 and $48 \mathrm{~h}$, respectively (Table 4). However, the methanolic extract of $P$. neochilus presented a $\mathrm{CC}_{50}$ value of $111 \mu \mathrm{g} / \mathrm{mL}$ when incubated with peritoneal macrophages after 72 hours of incubation. ${ }^{20}$

According to one study, a selectivity index (SI) value greater than 10 can suggest better safety of the product for use in mammals. ${ }^{31}$ The hexane extract of $B$. sulphurea showed a SI of 1.23 and 1.98 in $24 \mathrm{~h}$ and $48 \mathrm{~h}$, respectively. In addition, the hexane extract of $P$. neochilus showed a SI of 1.44 and 0.79 in $24 \mathrm{~h}$ and $48 \mathrm{~h}$, respectively, Despite the low SI, the hexane extracts showed values close to those obtained by amphotericin B, with a SI of 390 and 248.3 in $24 \mathrm{~h}$ and $48 \mathrm{~h}$, respectively (Table 4 )

One of the main treatments for leishmaniasis is the use of pentavalent antimony as a first-line and amphotericin B as a secondline. One of the biggest problems associated with this regimen is the need for intravenous or intramuscular administration for both medicines. ${ }^{5}$ Thus, there is concern about the effect of these or other proposed compounds or extracts with antileishmanial activity with respect to hemolytic activity. In determining the hemolytic activity of the hexane extracts from $B$. sulphurea and $P$. neochilus, we observed that the extracts showed no hemolytic activity at the concentrations evaluated, and the $\mathrm{HC}_{50}$ values were higher than $100 \mu \mathrm{g} / \mathrm{mL}$ for $B$. sulphurea and P. neochilus (Table 4).

Recently, the chemical composition of the hexane extract of $P$. neochilus was determined by gas chromatography-mass spectrometry (GC-MS). A total of thirteen compounds were detected, with predominance of sesquiterpenes $(88.8 \%)$. The major constituents were identified as being spathulenol $(46.1 \%)$, trans-caryophyllene $(19.0 \%)$, caryophyllene oxide $(10.7 \%)$ and germacrene D $(7.8 \%) .^{13}$ According toAcebey and co-workers, the sesquiterpene spathulenol, isolated from an ethyl acetate extract of the bark of Hedyosmum angustifolium, did not show activity against $L$. (L.) amazonensis and $L$. (L.) infantum in vitro. ${ }^{32}$ This could indicate that some other compounds may be responsible for the activity of the extract. The other major constituents were already described in extracts or essential oils, but their isolated activity was not been described. ${ }^{33,34}$ Thus, the activity of the isolates should be better investigated against parasites from genus Leishmania sp.

In our study, a total of fifteen compounds were detected on the $B$. sulphurea hexane extract and the major constituents were identified as being 2,4-bis(dimethylbenzyl)phenol (54.1\%), (3-tert-butyl-5hydroxymethyl-cyclohex-2-enyl)-methanol $(8.1 \%)$, pulegol $(7.3 \%)$ and (2-Dodecen-1-yl-succinic anhydride (7.2\%) (Table 5). This is the first study describing the effects of the major constituents of $B$. sulphurea extract on protozoa. 
Table 3 Effective concentration of 50\% against promastigotes and amastigotes after 24 and $48 \mathrm{~h}$ of incubation with the extracts B. sulphurea, P. neochilus and amphotericin B

\begin{tabular}{cccc}
\hline \multirow{2}{*}{ Compound } & $\mathbf{E C}_{\mathbf{5 0}}$ values against promastigotes $(\mu \mathbf{g} / \mathbf{m L})(\mathbf{9 5} \% \mathbf{C I})$ & $\mathbf{E C}_{\mathbf{5 0}}$ values against amastigotes $(\mu \mathbf{g} / \mathbf{m L})(\mathbf{9 5} \% \mathbf{C I})$ \\
\cline { 2 - 4 } & $\mathbf{2 4} \mathbf{~ h}$ & $\mathbf{4 8 h}$ & $\mathbf{4 8 h}$ \\
\hline B. sulphurea & $84.26(81.23-87.56)$ & $40.37(29.64-55.64)$ & $371.00(254.00-487.00)$ \\
P. neochilus & $46.32(38.42-57.54)$ & $43.20(36.57-50.87)$ & $141.00(90.09-192.4)$ \\
Amphotericin B & $0.011(0.0058-0.019)$ & $0.012(0.0063-0.022)$ & $0.095(0.07-0.012)$ \\
\hline
\end{tabular}

$\mathrm{Cl}$ : Confidence Interval of $95 \%$

Table 4 Cytotoxic Concentration of $50 \%$, Hemolytic Concentration of $50 \%$ and Selectivity Index obtained after 24 and $48 \mathrm{~h}$ of incubation with the extracts $B$. sulphurea, P. neochilus and amphotericin B

\begin{tabular}{|c|c|c|c|c|c|}
\hline \multirow{2}{*}{ Compound } & \multicolumn{2}{|c|}{$\mathrm{CC}_{50}$ values against murine macrophages $(\mu \mathrm{g} / \mathrm{mL})(95 \% \mathrm{CI})$} & \multirow{2}{*}{$\begin{array}{c}\mathrm{HC}_{50}(\mu \mathrm{g} / \mathrm{mL}) \\
(95 \% \mathrm{CI})\end{array}$} & \multicolumn{2}{|c|}{ Selectivity Index(SI) } \\
\hline & $24 \mathrm{~h}$ & $48 \mathrm{~h}$ & & $24 \mathrm{~h}$ & $48 \mathrm{~h}$ \\
\hline B. sulphurea & $103.9(99.46-128.98)$ & $80.30(73.15-88.15)$ & $>100$ & 1.23 & 1.98 \\
\hline P. neochilus & $66.95(59.55-75.27)$ & $34.39(28.21-41.93)$ & $>100$ & 1.44 & 0.79 \\
\hline Amphotericin B & $4.29(3.25-6.77)$ & $2.98(1.41-3.87)$ & $40.42(36.69-44.15)$ & 390 & 248.3 \\
\hline
\end{tabular}

\section{$\mathrm{Cl}$ : Confidence Interval of $95 \%$}

*Value obtained using the $\mathrm{EC}_{50}$ from promastigotes assays as described by Londero and co-workers. ${ }^{19}$

Table 5 Chemical composition of the hexane extract of Bidens sulphurea

\begin{tabular}{|c|c|c|c|}
\hline Compound & RT(min) & RI & $\% \mathbf{R A}$ \\
\hline 3,3-Dimethoxy-2-butanone & 3.23 & 826 & 0.8 \\
\hline 1-Methyl-2-(3-methylpentyl)cyclopropane & 5.86 & 914 & 0.7 \\
\hline 2-ethyl-1,3-Dioxolane-4-methanol & 9.45 & 1036 & 1.2 \\
\hline Pulegol & 13.25 & 1141 & 7.6 \\
\hline Citronellyl propionate & 25.11 & 1447 & 0.4 \\
\hline (3-tert-Butyl-5-hydroxymethyl-cyclohex-2-enyl)-methanol & 31.16 & 1614 & 8.4 \\
\hline 10,10-Dimethoxy-3,7-dimethyl-deca-2,6-dien-1-ol & 34.58 & 1714 & 0.2 \\
\hline Palmitaldehyde & 37.96 & 1818 & 4.9 \\
\hline Neophytadiene & 38.31 & 1829 & 0.9 \\
\hline 1-methyl-spiro[2.3]hexane-5-carboxylic acid menthyl ester & 38.70 & 1842 & 0.2 \\
\hline Phytone & 38.88 & 1847 & 4.5 \\
\hline E-phytol & 41.83 & 1946 & 4.2 \\
\hline 2-Dodecen-1-yl-succinic anhydride & 42.36 & 1961 & 7.5 \\
\hline Oxalic acid. docecyl isohexyl ester & 48.51 & 2276 & 0.8 \\
\hline 2.4-Bis(1-methyl-1-phenylethyl)phenol & 51.58 & 2491 & 56.3 \\
\hline Total & & & 98.7 \\
\hline
\end{tabular}

RT, retention time(min); RA, relative content calculated from the peak area relative to the total peak area in the GC-FID chromatogram; values are averages of three replicates; Compound identification, Comparison of the SI(Similarity Index) and retention index(RI) with those from mass spectra Wiley 7, NIST 08, and FFNSC I.2 spectral libraries.

\section{Conclusion}

The hexane extracts were evaluated in vitro in relation to the protozoan $L$. (L.) amazonensis and the results demonstrate a moderate leishmanicidal activity after 24 and $48 \mathrm{~h}$ of incubation. Despite the unsatisfactory results against amastigotes forms, this study shows extracts obtained from botanical sources merit further study for their leishmanicidal properties.

\section{Acknowledgments}

The authors are grateful to the National Council for Scientific and Technological Development, Brazil-CNPq and Centro Técnico Agropecuário (Centagro) for fellowships, and to the São Paulo Research Foundation, Brazil-FAPESP for financial support (Grant numbers 2013/11164-4). We also thank Jason Kim for the grammatical correction. 


\section{Conflicts of interest}

The authors have declared that there are no conflicts of interest.

\section{References}

1. de Vries HJC, Reedijk SH, Schallig HD. Cutaneous Leishmaniasis: Recent Developments in Diagnosis and Management. Am J Clin Dermatol. 2015;16(2):99-109.

2. Ghorbani M, Farhoudi R. Leishmaniasis in humans: Drug or vaccine therapy? Drug Des Devel Ther. 2018;12:25-40.

3. Dorlo TPC, Balasegaram M, Beijnen JH, et al. Miltefosine: a review of its pharmacology and therapeutic efficacy in the treatment of leishmaniasis. J Antimicrob Chemother. 2012;67(11):2576-2597.

4. http://www.who.int/leishmaniasis/en/

5. Brazil M of health. Manual of Surveillance of Intestinal Leishmaniasis. $1^{\text {st }}$ edn. (Secretariat of Health Surveillance, ed.). Brasilia: Ministry of Health; 2017.

6. Pereira JC, Ramos TD, Silva JD, et al. Effects of bone marrow mesenchymal stromal cell therapy in experimental cutaneous leishmaniasis in BALB/c mice induced by leishmania amazonensis Front Immunol. 2017;8:1-11.

7. Barral A, Pedral-Sampaio D, Grimaldi G, et al. Leishmaniasis in Bahia, Brazi: Evidence that Leishmania amazonensis produces a wide spectrum of clinical disease. Am J Trop Med Hyg. 1991;44(5):536-546.

8. Negrão F, Eberlin MN, Giorgio S. Proteomic approaches for drug discovery against tegumentary leishmaniasis. Biomed Pharmacother. 2017;95:577-582.

9. Croft SL, Sundar S, Fairlamb AH. Drug Resistance in Leishmaniasis Clin Microbiol Rev. 2006;19(1):111-126.

10. Attemene SDD, Beourou S, Tuo K, et al. Antiplasmodial activity of two medicinal plants against clinical isolates of Plasmodium falciparum and Plasmodium berghei infected mice. J Parasit Dis. 2018;42(1):68-76.

11. Kaur R, Kaur S. Evaluation of in vitro and in vivo antileishmanial potential of bergenin rich Bergenia ligulata (Wall.) Engl. root extract against visceral leishmaniasis in inbred BALB/c mice through immunomodulation. $J$ Tradit Complement Med. 2018;8(1):251-260.

12. Nibret E, Wink M. Trypanocidal and antileukaemic effects of the essential oils of Hagenia abyssinica, Leonotis ocymifolia, Moringa stenopetala, and their main individual constituents. Phytomedicine. 2010;17(12):911-920.

13. Dias HJ, Vieira TM, Carvalho CE, et al. Screening of Selected Plant-Derived Extracts for Their Antimicrobial Activity against Oral Pathogens. Intrnacional J Complement Altern Med. 2017;6(3):00188.

14. van Den Dool H, Kratz P. A generalization of the retention index system including linear temperature programmed gas-liquid partition chromatography. J Chromatogr A. 1963;11(3):463-471.

15. Lima GS, Castro-Pinto DB, MacHado GC, et al. Antileishmanial activity and trypanothione reductase effects of terpenes from the Amazonian species Croton cajucara Benth (Euphorbiaceae). Phytomedicine. 2015;22(12):1133-1137.

16. Kobayashi S, Hamashima S, Homma T, et al. Cystine/glutamate transporter, system $\mathrm{xc}^{-}$, is involved in nitric oxide production in mouse peritoneal macrophages. Nitric Oxide. 2018;78:32-40.

17. Sueth-Santiago V, De Moraes JBB, Alves ESS, et al. The effectiveness of natural diarylheptanoids against Trypanosoma cruzi: Cytotoxicity, ultrastructural alterations and molecular modeling studies. PLoS One. 2016;11(9):e0162926.
18. Lazcano-Pérez F, Zavala-Moreno A, Rufino-González Y, et al Hemolytic, anticancer and antigiardial activity of Palythoa caribaeorum venom. J Venom Anim Toxins Incl Trop Dis. 2018;24(1):1-7.

19. Londero VS, da Costa-Silva TA, Gomes KS, et al. Acetylenic fatty acids from Porcelia macrocarpa (Annonaceae) against trypomastigotes of Trypanosoma cruzi: Effect of octadec-9-ynoic acid in plasma membrane electric potential. Bioorg Chem. 2018;78:307-311.

20. Antinarelli LMR, Pinto NC, Scio E, et al. Antileishmanial activity of some brazilian plants, with particular reference to Casearia sylvestris. An Acad Bras Cienc. 2015;87(2):733-742.

21. Cortez de Sá J, Almeida-Souza F, Mondêgo-Oliveira R, et al Leishmanicidal, cytotoxicity and wound healing potential of Arrabidaea chica Verlot. BMC Complement Altern Med. 2016;16(1):1-11.

22. Emami SA, Rabe SZT, Ahi A, et al. Inhibitory Activity of Eleven Artemisia Species from Iran against Leishmania Major Parasites. Iran J Basic Med Sci. 2012;15(2):807-811.

23. Rodrigues IA, Azevedo MMB, Chaves FCM, et al. Arrabidaea chica hexanic extract induces mitochondrion damage and peptidase inhibition on Leishmania spp. Biomed Res Int. 2014;2014.

24. Singh SK, Bimal S, Narayan S, et al. Leishmania donovani: Assessmen of leishmanicidal effects of herbal extracts obtained from plants in the visceral leishmaniasis endemic area of Bihar, India. Exp Parasitol. 2011;127(2):552-558.

25. Escobar P, Leal SM, Herrera LV, et al. Chemical composition and antiprotozoal activities of Colombian Lippia spp essential oils and their major components. Mem Inst Oswaldo Cruz. 2010;105(2):184-190.

26. Maquiaveli CDC, Oliveira E Sá AM, Vieira PC, et al. Stachytarpheta cayennensis extract inhibits promastigote and amastigote growth in Leishmania amazonensis via parasite arginase inhibition. $J$ Ethnopharmacol. 2016;192:108-113.

27. Osorio E, Arango GJ, Jiménez N, et al. Antiprotozoal and cytotoxic activities in vitro of Colombian Annonaceae. J Ethnopharmacol. 2007;111(3):630-635.

28. Tempone AG, Sartorelli P, Teixeira D, et al. Brazilian flora extracts as source of novel antileishmanial and antifungal compounds. Mem Inst Oswaldo Cruz. 2008;103(5):443-449.

29. Fadel H, Sifaoui I, López-Arencibia A, et al. Assessment of the antiprotozoal activity of Pulicaria inuloides extracts, an Algerian medicinal plant: leishmanicidal bioguided fractionation. Parasitol Res. 2018;117(2):531-537.

30. Marango SN, Khayeka-Wandabwa C, Makwali JA, et al. Experimental therapeutic assays of Tephrosia vogelii against Leishmania major infection in murine model: In vitro and in vivo. BMC Res Notes. 2017;10(1):698.

31. Monzote L, Piñón A, Setzer W. Antileishmanial Potential of Tropical Rainforest Plant Extracts. Medicines. 2014;1(1):32-55.

32. Acebey L, Jullian V, Sereno D, et al. Anti-leishmanial lindenane sesquiterpenes from hedyosmum angustifolium. Planta Med. 2010;76(4):365-368.

33. Monzote L, Geroldinger G, Sarkar S De, et al. Interaction of ascaridole, carvacrol, and caryophyllene oxide from essential oil of Chenopodium ambrosioides L. with mitochondria in Leishmania and other eukaryotes. Phyther Res. 2018;32(9):1729-1740.

34. Moreira RRD, Martins GZ, Varandas R, et al. Composition and leishmanicidal activity of the essential oil of Vernonia polyanthes Less (Asteraceae). Nat Prod Res. 2017;31(24):2905-2908. 